Original Research Paper

\title{
Assessing of Soil Compaction and Relations to Soil Fertility on Different Land Used in Bintulu, Sarawak
}

\author{
${ }^{1}$ Aiza Shaliha Jamaluddin, 1,3* Arifin Abdu, 1,3 Hazandy Abdul Hamid, ${ }^{2}$ Shamshuddin Jusop, \\ ${ }^{2}$ Daljit Singh Karam Singh, ${ }^{1,3,4}$ Md. Rezaul Karim, ${ }^{4}$ Md. Suzauddula and ${ }^{2}$ Aizul Azfar Zulkeefli \\ ${ }^{I}$ Department of Forest Management, Faculty of Forestry, Universiti Putra Malaysia, 43400 Serdang, Selangor, Malaysia \\ ${ }^{2}$ Department of Land Management, Faculty of Agriculture, Universiti Putra Malaysia, 43400 Serdang, Selangor, Malaysia \\ ${ }^{3}$ Laboratory of Sustainable Bioresource Management, Institute of Tropical Forestry and Forest Product, \\ Universiti Putra Malaysia, 43400 Serdang, Selangor, Malaysia \\ ${ }^{4}$ Department of Nutrition and Food Engineering, Daffodil International University, Dhaka, Bangladesh
}

\section{Article history}

Received: 18-04-2016

Revised: 01-04-2020

Accepted: 08-06-2020

Corresponding Author

Arifin Abdu

Department of Forest

Management, Faculty of

Forestry, Universiti Putra

Malaysia, 43400 Serdang,

Selangor, Malaysia

Email: arifin_soil@yahoo.com

\begin{abstract}
Assessing land uses-induced changes in soil properties from natural forests to farmland are indispensable for addressing the complications in terms of agricultural landscape sustainability. A study was conducted in Rehabilitated Forest (RF), Oil Palm (OP), Secondary Forest (SF) and Rubber Plantation (RP) at University Putra Malaysia in order to examine the results of soil densification on soil characteristics and fertility status via soil indices. Soils were sampled at two soil depths. Fall-corn-type soil penetrometer was used to examine Soil compaction. Status of the soil fertility was determined by using Soil Evaluation Factor (SEF) and Soil Fertility Index (SFI). The soil compaction was severe at $\mathrm{RP}$ and OP compared to SF and RF. The highest $\mathrm{pH}$, total carbon and cation exchange capacity was recorded at RP site. Soil at OP was found highest organic matter content, nitrogen and available Al. The SFI was comparatively upper than SEF value in case of both depths. The highest SFI value was OP, followed by RP, RF and SF for the surface soil. Therefore, soil fertility were affected by different types of trees such as dipterocarp trees, oil palm trees and rubber trees as well as soil managements and it is required to develop appropriate land use policy, sustainable soil management and cultivation practices to face the recent soil degradation in the study area.
\end{abstract}

Keywords: Soil Compaction, Physical and Chemical Properties, Soil Fertility, SFI, SEF

\section{Introduction}

In global ecosystems soil is not only an important constituent but also it plays an important function in forestry and farming systems (Beheshti et al., 2012). A recent chronosequence study documented of the effects of soil-use and soil fertility on regaining forest arrangement and species and the site quality of forests (Chinea, 2002; Pascarella et al., 2000). The extensive land use, specifically conversion of natural forests to agricultural land, may affect in soil progressions and properties and consequently soil functioning (Beheshti et al., 2012). Several study have pointed out that changes in land use would impact on the fertility and features of the soils because of subsequent modifications in biotic and abiotic factors (Solomon et al., 2000; Raise,
2007) and also govern the soil physical, chemical and microbial processes (Celik, 2005; Raise, 2007; Beheshti et al., 2012). Agriculture activities also result in a change of the aggregation-range of spreading and stability. The vital affiliation among Soil Organic Carbon (SOC), activity of microorganisms, aggregate-size and stability has been identified through several past study (Celik, 2005; Raise, 2007; Li et al., 2009).

There have some recognized factors which are responsible for lower crop production, composition of soil is one of them. At present composition of soil is considered to be a multi-dimensional problem in which some factors (machine, soil, crop and weather interactions) play valuable role and which may have serious environmental and economic consequences in 
forest and agriculture lands (Soane and Ouwerkerk, 1995). Soil compaction a term which is closely linked with soil bulk and soil pore density had broadly studied as indicator of land use quality or additional environmental factors (Mattsson et al., 2000).

Soil nutrient contents are naturally greater in undisturbed lands, such as wetlands, natural forests and grasslands, than in converted croplands or planted forests (Tanaka et al., 2009; Moscatelli et al., 2007; Ouyang et al., 2013a). Beheshti et al. (2012) specified that when forests have been transformed for rice and rubber cultivation and perennial cash crops, serious tillage practices reduce the soil organic carbon and nitrogen storage in the topsoil. Quantity of soil nutrient are also expected to be renewable in farming systems through management of tillage, changing the way of land with well-organized and systematic farming practices, that's may beas like irrigation and the use of fertilizer or biodegradable pesticides (Reijneveld et al., 2009; Tanaka et al., 2009; Aweto, 1987; Wicke et al., 2011). Moran et al. (2000) stated that soil fertility and texture strongly affect the rates of recovery of forest from anthropogenic disturbances (such as traditional shifting cultivation, agroforestry, mechanized agriculture, or cattle ranching). Johnson et al. (2000) stated that both soil fertility and soil moisture tend to covay with soil texture.

The use of soil fertility indices can help estimate the impact of agricultural practices and forest management for soil properties can be identified. The evaluation of the soil quality and the identification of vital soil composition that serve as indicators of the functional properties of soil, is complicated by several issues defining quality and diversity of biological, chemical and physical factor which control the soil processes (Doran and Parkin, 1994). To identify the condition of soils due to land use changes during agricultural practices and forest management achieves an optimum level, the nutritional status of soil status must be evaluated. For Sustainable ameliorating agriculture, making land use practice and forest management practice are important and characteristics of how soil is changing and it's effect on soil nutrition is very important to ensure the sustainability. Several researchers have emphasized on soil properties of tropical rainforest in Malaysia, but the consequence of soil compaction on soil properties and fertility status using soil indices are lacking or still limited. Therefore, the aim of this study was (1) to evaluate the effect of soil compaction/hardness on it properties and soil fertility status of the study area using soil indices (2) to evaluate the effect of land uses and their supervision on soil physio-chemical properties; (3) to judge the general affairs of some particular soil physio-chemical function (4) to evaluate the nutrient level of soil under several management. Thusly, such limited correlation of the conceivable linkage between land use changes and soil properties could be important to distinguish land utilizes that are positive for improved supplements and soil carbon stockpiling and answerable for supplement and soil carbon consumption. The out puts of this examination could help for advancement of a proper land utilize arranging and reasonable land assets the board and subsequently for development of the vocation of the agrarian network in the investigation region and other comparable agro-natural Zone.

\section{Materials and Methods}

\section{Study Site}

This study was conducted under Rehabilitated Forest (RF), Secondary Forest (SF), Oil Palm plantation (OP) and Rubber Plantation (RP) at Universiti Putra Malaysia Bintulu Campus in Sarawak, Malaysia and used in order to compare the physico-chemical properties and soil fertility status (Fig. 1). It is located about $600 \mathrm{~km}$ northeast of Kuching the capital city of Sarawak, latitude $03^{\circ} 12^{\prime} \mathrm{N}$, longitude $113^{\circ} 02^{\prime} \mathrm{E}$ and $50 \mathrm{~m}$ above sea level.

\section{Soil Sampling and Analysis}

Soils were sampled in plots size $20 \times 20 \mathrm{~m}$ for each site. Every plot was categorized into two sub-plots. The samples (soil) were taken from two difference depths, i.e., surface $(0-15 \mathrm{~cm})$ and subsurface $(15-30 \mathrm{~cm})$ from every edge and in the center of the plot by using soil borer in addition of that homogenizer to prepared the composite samples. The moisture of sample were removed through air then blend and sieved with a two $\mathrm{mm}$ mesh sieve for physical and chemical analyses.

The assessment of soil compaction was done at RF, SF, OP and RP. Three replications were done in each plot, which is covered from top, middle and bottom of the plots. Soil compaction was measured using fall-corntype soil penetrometer (Hasegawa Type H-60) until the depth of $50 \mathrm{~cm}$. Horizontal axis represents the penetrating depth $(\mathrm{cm})$ per one drop of weight (termed as One Drop Penetrability, ODP) and vertical axis does the cumulative depth $(\mathrm{cm})$. In this study, soil compaction is classified using the value plotted of the horizontal axis as follows: very hard, ODP $<0.5 \mathrm{~cm}$; hard, ODP between 0.5-1.0 cm; moderate, ODP between 1.0- $2.0 \mathrm{~cm}$; soft, ODP > $2.0 \mathrm{~cm}$ (Ishizuka et al., 1998).

Soil $\mathrm{pH}$ was determined in water or $1 \mathrm{M} \mathrm{KCl}$ in a soil to solution ratio of 1:2.5 using glass electrodes after reciprocal shaking for 1 hour (Jones, 2001). Soil 
organic matter and total organic carbon were determined using $10 \mathrm{~g}$ of soil by loss-on-ignition method (Ben-Dor and Banin, 1989). Total Nitrogen was determined using Kjeldahl method (Bremner and Mulvaney, 1982) and total carbon in soil was determined by dry-combustion method (Schumacher, 2002) using $10 \mathrm{~g}$ of soil by LECO-412 analyzer machine. Transferrable elementary cations ( $\mathrm{K}, \mathrm{Ca}, \mathrm{Mg}$ and $\mathrm{Na}$ ) were take out with $1 \mathrm{M}$ NH4OAc buffered at $\mathrm{pH}$ 7. The combination of $\mathrm{K}, \mathrm{Ca}, \mathrm{Mg}$ and $\mathrm{Na}$ in the solutions were measured by AAS - Shimadzu AA6800. Cation Exchange Capacity (CEC) was examined by $0.05 \mathrm{M} \mathrm{K} 2 \mathrm{SO} 4$ using the soil used for the basic transferrable cation determination. Then, the soil was scrubbed with $100 \mathrm{~mL}$ of ethanol (95\%). Exchangeable acidity and exchangeable Al were pull out with $1 \mathrm{M}$ $\mathrm{KCl}$. The exchangeable acidity was justified by titration method with $0.01 \mathrm{M} \mathrm{NaOH}$ and the content of exchangeable Al with $0.01 \mathrm{M} \mathrm{HCl}$ (Sumner, 1992). Accessible phosphorus was identified by the Bray II method. In Soil obtainable phosphorus was extracted with a solution of $\mathrm{HCl}$ and $\mathrm{NH} 4 \mathrm{~F}$ (Bray and Kurtz, 1945). Particle-size spreading was identified using the pipette methods (Gee and Bauder, 1986).

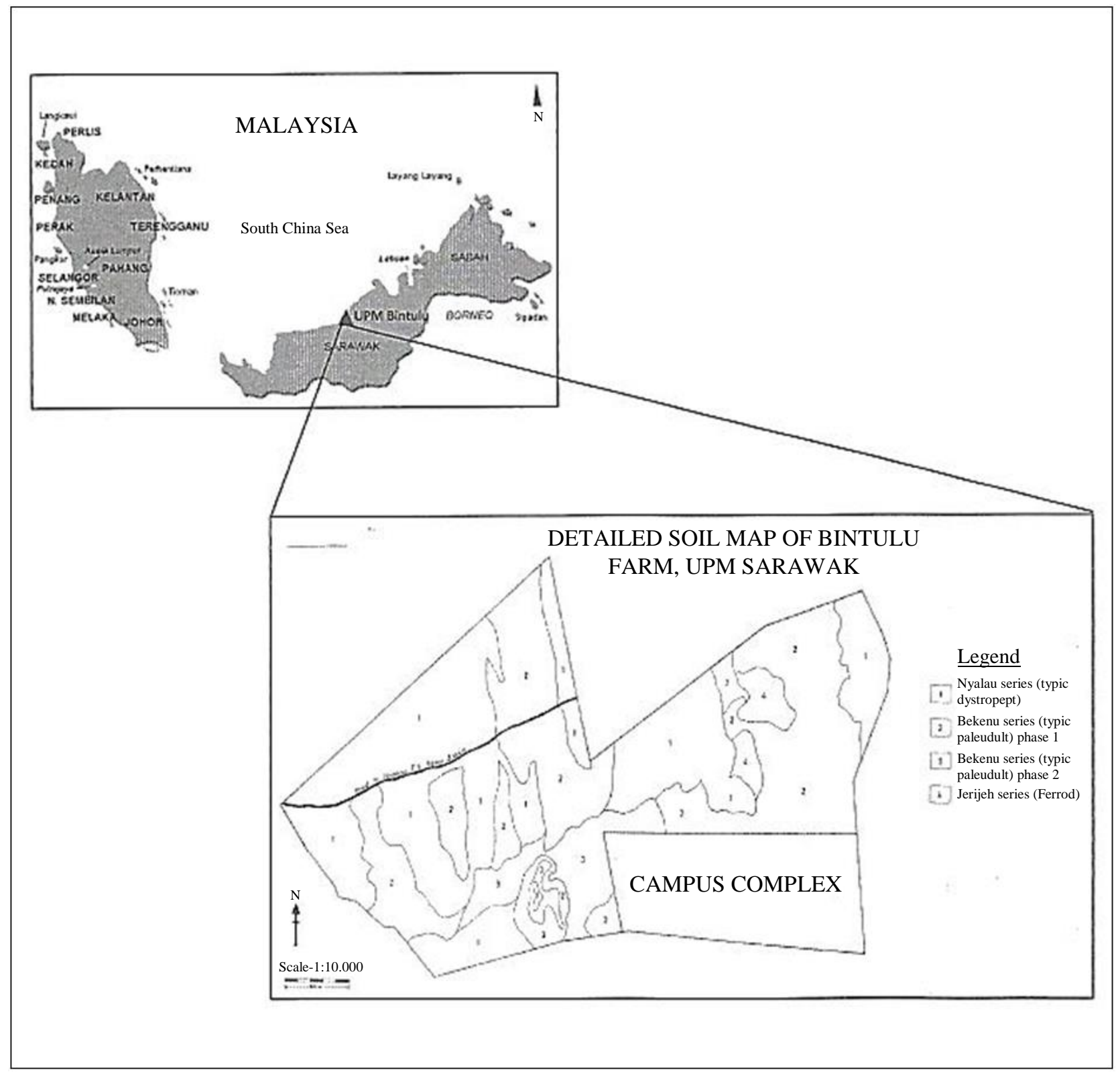

Fig. 1: Detailed soil map of UPM Bintulu Campus, Sarawak (modified from Peli et al., 1984) 
Soil Fertility Index (SFI) (Moran et al., 2000) and Soil Evaluation Factor (SEF) (Lu et al., 2002) were taken to gage the soil productiveness of these four dissimilar land uses. The SFI and SEF indices were analyzed to enumerate the intensity of land degradation where the study was conducted:

$$
\begin{aligned}
& \text { SFI }=p H+\text { Organic matter }(\% \text { dry soil basis }) \\
& + \text { Available } P\left(\mathrm{mgkg}^{-1} \text { dry soil }\right)+\text { Exchg.K }\left(\mathrm{cmol}_{c} \mathrm{~kg}^{-1}\right) \\
& + \text { Exchg.Ca }\left(\mathrm{cmol}_{c} \mathrm{~kg}^{-1}\right)+\text { Exchg.Mg }\left(\mathrm{cmol}_{c} \mathrm{~kg}^{-1}\right) \\
& - \text { Exchg.Al }\left(\mathrm{cmol}_{c} \mathrm{~kg}^{-1}\right) \\
& \text { SEF }=\left[\text { Exchg.K }\left(\mathrm{cmol}_{c} \mathrm{~kg}^{-1}\right)+\text { Exchg.Ca }\left(\mathrm{cmol}_{c} \mathrm{~kg}^{-1}\right)\right. \\
& + \text { Exchg } \mathrm{Mg}\left(\mathrm{cmol}_{c} \mathrm{~kg}^{-1}\right)-\log \left(1+\text { exchg.Al }\left(\mathrm{cmol}_{c} \mathrm{~kg}^{-1}\right)\right] \\
& \text { xOrganicmatter }(\% \text { dry soil basis })+5
\end{aligned}
$$

\section{Data Analysis}

An independent t-test was performed to detect any significant differences on the surface soils $(0-15 \mathrm{~cm})$ and subsurface soils $(15-30 \mathrm{~cm})$ for rehabilitated forest, secondary forest, oil palm and rubber plantations. General Linear Model (GLM) procedure was used to detect any significance differences of physico-chemical properties among different land uses followed by a postHoc Tukey's (HSD) for mean separation test. The
Statistical Analysis System (SAS) version 9.1 was used for the analysis.

\section{Results and Discussion}

\section{Soil Compaction and its Effects on Soil Properties}

The results in Fig. 2 showed that the soil compaction at rehabilitated forest from 0 to $3 \mathrm{~cm}$ depth was very soft with high ODP values, which means the soil was less compacted. The soil compaction at 4 to $11 \mathrm{~cm}$ depth showed the moderate ODP values. The soil became very hard towards the end from point of 12 to $49 \mathrm{~cm}$ depth. The soil compaction at secondary forest showed that the soil from 0 to $3 \mathrm{~cm}$ depth was very soft. The ODP value at 4 to $23 \mathrm{~cm}$ depth was soft and the soils turns to very soft at the point of 24 to $25 \mathrm{~cm}$ depth. In oil palm plantation area, from0 to $6 \mathrm{~cm}$ depth soil was very soft. At 7 to $27 \mathrm{~cm}$ showed that the soil was soft. The ODP value at the point of 28 to $41 \mathrm{~cm}$ depth showed the soil was moderately hard, while at 42 to $44 \mathrm{~cm}$ depth the soil was soft and then the soil turned to moderately hard. However, the rubber cultivation area at 0 to $7 \mathrm{~cm}$ depth showed that the soil was very soft. Then the soil was moderately hard from the point of 8 to $28 \mathrm{~cm}$ depth. The soil compaction from the point of 29 to $31 \mathrm{~cm}$ was very soft but, then it turned to moderately hard. Soil compaction measurement provides valuable information on soils to predict a significant physical hazard for plant growth (Sakurai et al., 1998).

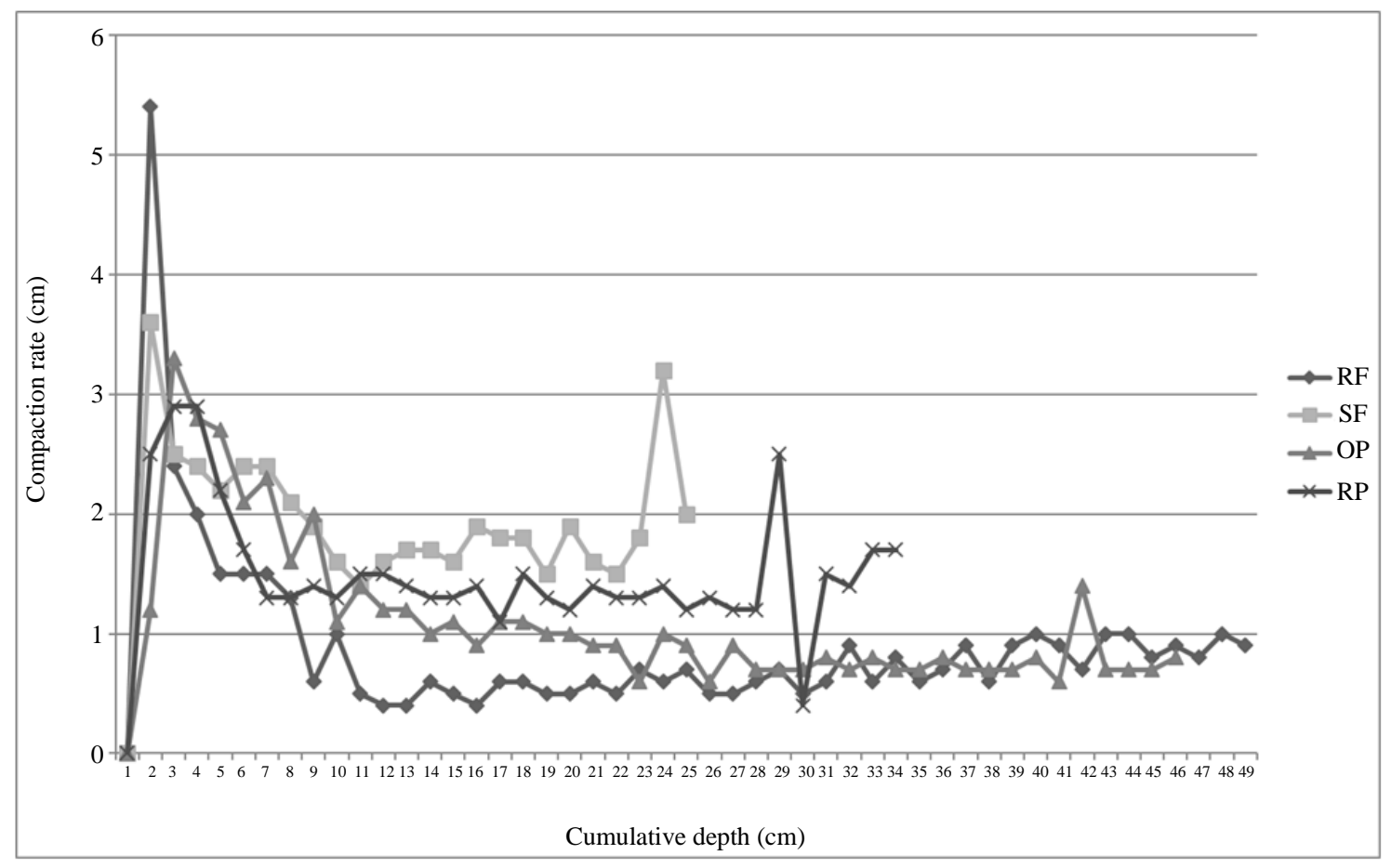

Fig. 2: The pattern of soil compaction at Rehabilitated Forest (RF), Secondary Forest (SF), Oil Palm (OP) and rubber plantations (RP) determined using fall-corn-type soil penetrometer (Hasegawa Type H-60) 
From our observation we found tap root system at rehabilitated forest and secondary forest trees and also rubber plantation while fibrous roots were found at oil palm trees. The upper roots are a key root descending downward from the fundamental and giving off tiny lateral roots. While, the fibrous roots grow from adventitious roots get out of bed from the plant's stem and habitually do not enter in the soil very deeply. Plants with fibrous root structures are especially suitable in averting soil erosion due to their roots accord themselves firmly to subdivision of soil. It is expected that the roots of tree at rehabilitated, secondary, oil palm and rubber trees were not elongated when ODP value is less than 0.5. Ishizuka et al. (1998) found in their study on distribution of soils at Lambir Hill National Park in Sarawak, Malaysia that the root cannot be elongated in steep slope area. The study by Ishizuka et al. (1998) stated that the physical hazard of soil hardness for root elongation was confirmed at some point within the slope area due to clay accumulation in the subsurface layers. The morphological and physical characteristic of the soil area was discussed by Aiza et al. (2012) and also found the same results.

The total count of soil compaction assessment down to $50 \mathrm{~cm}$ depth within the secondary forest and rubber cultivation areas was less than 25 and 34 drops, respectively. Considerably the soil in those areas less compaction and the roots can penetrate more into deeper layer of soil. The effects of rubber on soil physical properties are quite distinct from other food crops, which Nye and Greenland (1964) reported result in rapid deterioration in soil physical status and did not function as natural bush fallow vegetation that improves soil physical status over the time (Aweto, 1987). The ODP value at the secondary forest and rubber cultivation areas was almost 2.0 until the depth of $8 \mathrm{~cm}$, especially at the surface layer ODP value was very high because of welldeveloped forest litter.

Cumulative depth and graph pattern of soil compaction for rehabilitation forest and oil palm plantation longer than secondary forest and rubber cultivation. Total count of soil compaction measurement down to $50 \mathrm{~cm}$ at rehabilitation forest and oil palm plantation is almost more than 45 drops. The ODP value was less than 1.0 in the deeper layer of soil. It is indicating that there were little gravelly materials presented at the subsurface layer, which inhibited root penetration into the soil. The similar results also found by Ishizuka et al. (1998). However, uses of agricultural machinery and tree management might be contributed in increasing soil compaction at that site.

Outcomes indicated that equally in agricultural and forest soils, compaction not only decrease total soil absorbency but also modifies the pore structure. In fact, the fraction of lengthened pores, useful for water movement and root development is strongly reduced in compressed soil. The alterations to the pore system also change the form of soil structure. The massive and platy constructions are common feature in compacted soil. Results also exhibited that the lessening of porosity and of elongated pores following compaction is severely connected to the growth of penetration resistance and to the decrease of hydraulic conductivity and root growth (Pagliai et al., 2000).

\section{Characteristic of Soils at Different Depths}

In order to evaluate the effect of soil compaction on soil properties of RF, SF, OP and RP site, the soil properties at those sites were investigated. The results of soil physicochemical properties of the surface and subsurface for RF, SF, OP and RP site are shown in Table 1.

Table 1: Comparison of physico-chemical properties in surface and subsurface soils among the sites

\begin{tabular}{|c|c|c|c|c|c|c|c|c|}
\hline \multirow[b]{3}{*}{ Soil properties } & \multicolumn{8}{|l|}{ Sites } \\
\hline & \multicolumn{4}{|c|}{ Surface $(0-15 \mathrm{~cm})$} & \multicolumn{4}{|c|}{ Subsurface $(15-30 \mathrm{~cm})$} \\
\hline & $\mathrm{RF}$ & SF & $\mathrm{OP}$ & $\mathrm{RP}$ & $\mathrm{RF}$ & SF & $\mathrm{OP}$ & $\mathrm{RP}$ \\
\hline $\mathrm{pH}\left(\mathrm{H}_{2} \mathrm{O}\right)$ & $4.43^{\mathrm{a}}$ & $4.18^{\mathrm{a}}$ & $4.38^{\mathrm{a}}$ & $4.33^{\mathrm{a}}$ & $4.59^{\mathrm{a}}$ & $4.41^{\mathrm{a}}$ & $4.23^{\mathrm{a}}$ & $4.30^{\mathrm{a}}$ \\
\hline $\mathrm{pH}(\mathrm{KCl})$ & $3.65^{\mathrm{ab}}$ & $3.58^{\mathrm{b}}$ & $3.80^{\mathrm{a}}$ & $3.74^{\mathrm{ab}}$ & $3.83^{\mathrm{a}}$ & $3.82^{\mathrm{a}}$ & $3.78^{\mathrm{a}}$ & $3.77^{\mathrm{a}}$ \\
\hline $\mathrm{OM}(\%)$ & $5.14^{\mathrm{b}}$ & $5.03^{b}$ & $7.04^{\mathrm{a}}$ & $7.03^{\mathrm{a}}$ & $3.60^{\mathrm{b}}$ & $3.67^{\mathrm{b}}$ & $6.39^{a}$ & $6.79^{a}$ \\
\hline Total $\mathrm{C}\left(\mathrm{g} \mathrm{kg}^{-1}\right)$ & $1.71^{\mathrm{a}}$ & $1.94^{\mathrm{a}}$ & $1.90^{\mathrm{a}}$ & $2.02^{\mathrm{a}}$ & $1.06^{\mathrm{a}}$ & $1.11^{\mathrm{a}}$ & $0.95^{\mathrm{a}}$ & $0.81^{\mathrm{a}}$ \\
\hline Total N $\left(\mathrm{g} \mathrm{kg}^{-1}\right)$ & $2.23^{\mathrm{a}}$ & $2.95^{\mathrm{a}}$ & $3.10^{\mathrm{a}}$ & $2.65^{\mathrm{a}}$ & $2.79^{\mathrm{a}}$ & $2.40^{\mathrm{a}}$ & $2.19^{\mathrm{a}}$ & $3.02^{\mathrm{a}}$ \\
\hline $\mathrm{CEC}\left(\mathrm{cmol}_{\mathrm{c}} \mathrm{kg}^{-1}\right)$ & $5.28^{\mathrm{b}}$ & $5.13^{\mathrm{b}}$ & $12.36^{\mathrm{a}}$ & $13.04^{\mathrm{a}}$ & $5.63^{\mathrm{b}}$ & $4.18^{b}$ & $10.89^{\mathrm{a}}$ & $13.64^{\mathrm{a}}$ \\
\hline Exc. $\mathrm{K}\left(\mathrm{cmol}_{\mathrm{c}} \mathrm{kg}^{-1}\right)$ & $0.16^{\mathrm{a}}$ & $0.10^{\mathrm{b}}$ & $0.11^{\mathrm{b}}$ & $0.13^{\mathrm{ab}}$ & $0.09^{\mathrm{a}}$ & $0.10^{\mathrm{a}}$ & $0.05^{\mathrm{b}}$ & $0.03^{\mathrm{b}}$ \\
\hline Exc. $\mathrm{Ca}\left(\mathrm{cmol}_{\mathrm{c}} \mathrm{kg}^{-1}\right)$ & $0.27^{\mathrm{a}}$ & $0.08^{\mathrm{bc}}$ & $0.22^{\mathrm{ab}}$ & $0.02^{\mathrm{c}}$ & $0.16^{\mathrm{a}}$ & $0.08^{\mathrm{ab}}$ & $0.05^{\mathrm{b}}$ & $0.02^{\mathrm{b}}$ \\
\hline Exc. $\mathrm{Mg}\left(\mathrm{cmol}_{\mathrm{c}} \mathrm{kg}^{-1}\right)$ & $0.24^{\mathrm{a}}$ & $0.06^{\mathrm{b}}$ & $0.21^{\mathrm{ab}}$ & $0.24^{\mathrm{a}}$ & $0.14^{\mathrm{a}}$ & $0.04^{\mathrm{a}}$ & $0.10^{\mathrm{a}}$ & $0.07^{\mathrm{a}}$ \\
\hline Exc.Al $\left(\mathrm{cmol}_{\mathrm{c}} \mathrm{kg}^{-1}\right)$ & $1.13^{\mathrm{b}}$ & $1.98^{\mathrm{b}}$ & $2.21^{\mathrm{a}}$ & $2.09^{\mathrm{a}}$ & $1.10^{\mathrm{b}}$ & $1.27^{\mathrm{b}}$ & $2.99^{\mathrm{a}}$ & $2.71^{\mathrm{a}}$ \\
\hline Avail. $\mathrm{P}\left(\mathrm{mg} \mathrm{P} \mathrm{kg}^{-1}\right)$ & $2.68^{b}$ & $2.54^{\mathrm{b}}$ & $6.21^{\mathrm{a}}$ & $3.03^{\mathrm{b}}$ & $1.98^{\mathrm{a}}$ & $1.72^{\mathrm{a}}$ & $4.77^{\mathrm{a}}$ & $4.69^{\mathrm{a}}$ \\
\hline Clay $(\%)$ & $21.06^{\mathrm{a}}$ & $17.14^{\mathrm{a}}$ & $17.32^{\mathrm{a}}$ & $16.05^{\mathrm{a}}$ & $21.57^{\mathrm{b}}$ & $27.42^{\mathrm{ab}}$ & $21.98^{\mathrm{b}}$ & $31.94^{\mathrm{a}}$ \\
\hline Silt $(\%)$ & $39.33^{\mathrm{a}}$ & $16.05^{\mathrm{b}}$ & $41.44^{\mathrm{a}}$ & $21.93^{\mathrm{b}}$ & $35.33^{\mathrm{a}}$ & $16.75^{\mathrm{b}}$ & $37.76^{\mathrm{a}}$ & $28.98^{\mathrm{a}}$ \\
\hline Sand $(\%)$ & $39.51^{\mathrm{b}}$ & $66.78^{a}$ & $41.08^{b}$ & $61.90^{\mathrm{a}}$ & $43.04^{\mathrm{ab}}$ & $55.80^{\mathrm{a}}$ & $40.19^{\mathrm{b}}$ & $38.97^{b}$ \\
\hline
\end{tabular}

Note: Different superscripts letter(s) in the same row indicate significant differences among sites at $\mathrm{p} \leq 0.05$ using Tukey's HSD test 
The soil $\mathrm{pH}\left(\mathrm{pH}-\mathrm{H}_{2} \mathrm{O}\right.$ and $\mathrm{pH}-\mathrm{KCl}$ for all sites (Table 1) were acidic ranging from 4.18 to $4.43\left(\mathrm{pH}-\mathrm{H}_{2} \mathrm{O}\right)$ and 3.58 to 3.73 ( $\mathrm{pH}-\mathrm{KCl}$ ) for surface soil and, 4.23 to 4.59 $\left(\mathrm{pH}-\mathrm{H}_{2} \mathrm{O}\right)$ and 3.77 to $3.83(\mathrm{pH}-\mathrm{KCl})$ for subsurface soil, respectively. Rehabilitated forest held the highest value for both surface and subsurface soils. The results also showed that the soils for all sites were acidic $\left(\mathrm{pH}-\mathrm{H}_{2} \mathrm{O}\right.$ and $\mathrm{pH}-\mathrm{KCl}$ for both depths. Results from a study of tropical forest in Mexico stated that a low soil $\mathrm{pH}$ value found in old-growth forest soils was due to low quality organic matter accumulation, as well as the presence of recalcitrant materials such as lignin (Bautista-Cruz et al., 2012). Soil from the oil palm plantation and rubber plantation held the highest organic matter content for surface and subsurface soils compared to other sites. Beheshti et al. (2012) stated that land use changes and types are the factors that controlling organic matter sequestration in soil, as they affect the quantity and quality of organic inputs, litter decomposition rates and process of organic matter. Climate, especially heavy rainfall in tropical region is important in determining the amount of OM and total $\mathrm{N}$ losses from forest ecosystem. Besides that, Ouyang et al. (2013b) also reported that large soil organic matter losses occurs when native land is converted to agricultural land.

The total carbon was highest in the rubber plantation $\left(2.02 \mathrm{~g} \mathrm{~kg}^{-1}\right)$ for surface soil, while secondary forest $(1.11 \mathrm{~g}$ $\mathrm{kg}^{-1}$ ) held the highest for subsurface soil. The total nitrogen was the highest at oil palm plantation $\left(3.10 \mathrm{~g} \mathrm{~kg}^{-1}\right)$ for surface soil, while rubber plantation $\left(3.02 \mathrm{~g} \mathrm{~kg}^{-1}\right)$ held the highest value for subsurface soil. Beheshti et al. (2012) reported that the cultivated soil has a greater $\mathrm{C}$ and $\mathrm{N}$ content than forest soil due to distribution in the claysize fraction and turnover rate at the surface layer. The agricultural practices and land-use management are the factor that may cause the high total carbon content (Huang et al., 2007).

The Cation Exchange Capacity (CEC) was the highest in the rubber plantation for both surface and subsurface soils (13.04 and 13.64 cmol $_{\mathrm{c}} \mathrm{kg}^{-1}$, respectively). The lowest CEC value was at secondary forest (5.13 and $4.18 \mathrm{cmol}_{\mathrm{c}} \mathrm{kg}^{-1}$, respectively) for both depths. This indicates that the organic matter content for rubber plantation was higher than other sites. This explains that the decomposition rates of organic matter at rubber plantation were higher than other sites. Organic matter affects the CEC of soils (Heryati et al., 2011). Therefore, soils with high organic matter have higher CEC than soil with low organic matter (Hardjowigeno, 2007). The exchangeable $\mathrm{K}, \mathrm{Ca}$ and $\mathrm{Mg}$ were highest at rehabilitated forest with $0.16 \mathrm{cmol}_{\mathrm{c}} \mathrm{kg}^{-1}, 0.27 \mathrm{cmol}_{\mathrm{c}} \mathrm{kg}^{-1}$ and $0.24 \mathrm{cmol}_{\mathrm{c}} \mathrm{kg}^{-1}$, respectively at surface soil. While for subsurface soil the highest exchangeable $\mathrm{K}$ was at secondary forest $\left(0.10 \mathrm{cmol}_{\mathrm{c}} \mathrm{kg}^{-1}\right)$ and exchangeable $\mathrm{Ca}$ and $\mathrm{Mg}$ at rehabilitated forest $\left(0.16\right.$ and $0.14 \mathrm{cmol}_{\mathrm{c}} \mathrm{kg}^{-1}$, respectively). The exchangeable bases for all sites and both depth considered very low in comparison to the exchangeable Al. Lu et al. (2002) reported that the physical structure (compaction and particle composition) were related with nutrient accumulation, while chemical properties ( $\mathrm{K}, \mathrm{Ca}$ and $\mathrm{Mg}$ ) have significant effects on biomass accumulation. Tanaka et al. (2009) suggested that nutrient removal from soil by tapping is not negligible although tapping activity continues for more than 10 years. However, tapping activities related to high intensity of rubber latex production and it might be contributed to nutrient depletion in soils.

The exchangeable Al for surface soil was highest at oil palm plantation $\left(2.21 \mathrm{cmol}_{\mathrm{c}} \mathrm{kg}^{-1}\right)$ and the lowest was at rehabilitated forest $\left(1.13 \mathrm{cmol}_{\mathrm{c}} \mathrm{kg}^{-1}\right)$. While for subsurface soil, the highest exchangeable Al was also at oil palm plantation $\left(2.99 \mathrm{cmol}_{\mathrm{c}} \mathrm{kg}^{-1}\right)$ and lowest at rehabilitated forest $\left(1.10 \mathrm{cmol}_{\mathrm{c}} \mathrm{kg}^{-1}\right)$. The high level of exchangeable $\mathrm{Al}$ could be the reason of low availability of other nutrients such as $\mathrm{K}, \mathrm{Ca}, \mathrm{Mg}$ and particularly phosphorus because these nutrients was fixed by Al, so it could not be used by plants for its growth (Hardjowigeno, 2007). The ability of roots to absorb nutrients also restricted due to high level of exchangeable Al. The available $\mathrm{P}$ was highest at oil palm plantation (6.21 $\mathrm{mg} \mathrm{kg}^{-1}$ and $4.77 \mathrm{mg} \mathrm{kg}^{-1}$ ) and the lowest at secondary forest $\left(2.54 \mathrm{mg} \mathrm{kg}^{-1}\right.$ and $1.72 \mathrm{mg}$ $\mathrm{kg}^{-1}$ ) for surface and subsurface soils respectively. The high amount of available $\mathrm{P}$ in oil palm may be due to accumulation of phosphorus fertilizer in the soil (Ouyang et al., 2013a). According to Lal (1997), in tropical region, one of the limiting factors of forest productivity is low in phosphorus content. But every tree species demands phosphorus differently and some of them have better capacity to extract phosphorus in fixed form from soils (Heryati et al., 2011).

The clay composition was the highest at rehabilitated forest $(21.06 \%)$, while the lowest at rubber plantation $(16.05 \%)$ for surface soil. At subsurface soil, the highest clay composition was at rubber plantation $(31.94 \%)$ and the lowest was rehabilitated forest $(21.57 \%)$. The silt composition was the highest at oil palm plantation $(41.44 \%$ and $37.76 \%)$ and the lowest at secondary forest $(16.05 \%$ and $16.75 \%)$ for surface and subsurface soils, respectively. While for sand composition, the highest value was at secondary forest for both depths $(66.78 \%$ and $55.80 \%)$ and the lowest value was at rehabilitated forest $(39.51 \%)$ for surface soil and rubber plantation (38.97\%) for subsurface soil. According to Lu et al. (2002), physical structure is related to nutrient retention in the soil layers. The soil texture for these soils can be classified into loamy (rehabilitated forest and oil palm plantation) and sandy clay loam to silty loam (secondary forest and rubber plantation) (Aiza et al., 2012). Higher clay content 
associated with lower sand composition can hold more nutrients in the soils. Conversely, low in clay content associated with high sand content result in low nutrients retention in soil (Heryati et al., 2011).

\section{Assessing soil Fertility Status Using Soil Indices}

The dissimilarities in soil properties make it tough to find aappropriate method to judge the soil conditions in tropical forests. Consequently, Moran et al. (2000) and $\mathrm{Lu}$ et al. (2002) had established a method for approximating soil fertility and site excellence called Soil Fertility Index (SFI) and Soil Evaluation Factor (SEF). The methods were used to assessment soil fertility and site productivity under different progression stage of secondary forest in tropical Amazon (Heryati et al., 2011). Mutually SFI and SEF are valid for assessing soil fertility and site quality under dipterocarp plantation in transformed degraded forestland in Perak, Malaysia (Arifin et al., 2008; Zaidey et al., 2010). The question remains, are these fertility indices applicable to an agricultural system? A suitable soil quality indictor must be sensitive to as many degrading agents as possible, show a consistent directional change in response to a given contaminant and be able to reflect different levels of degradation (Elliott, 1997). Zornoza et al. (2008) also stated that to obtain the accuracy and sensitivity of indices organic matter content are most important indicator that reflect in physical, chemical and biological properties in the soils.
The SFI and SEF values for surface and subsurface soils are shown in Fig. 3 and 4 for all sites. Figure 3 and 4 showed that the value of SFI was higher than SEF value at both depths. The highest SFI value was at oil palm plantation (11.97) followed by rubber plantation (11.44), rehabilitated forest (9.30) and secondary forest (7.77) for surface soil. While for subsurface soil, the SFI value was highest at rubber plantation (11.03) followed by oil palm plantation (10.66), rehabilitated forest (7.90) and secondary forest (7.18). However, the SEF values were lower compared to SFI values for all sites and depths. The highest SEF value was at rehabilitated forest (5.70) followed by oil palm (5.29), rubber plantation (4.31) and secondary forest (3.21), respectively for surface soil. While for subsurface soil, the highest value was at rehabilitated forest (4.56) followed by secondary forest (3.89), oil palm plantation (3.73) and rubber plantation (2.99). The SEF values for subsurface soil for all sites were lower compared to surface soil, excepted for secondary forest.

It is indicating that the soil in the crop plantation areas held more nutrient content compared to rehabilitated forest. This is happened due to fertilization for a long period of time in the plantation areas (oil palm and rubber). The soils under secondary forest in this study were characterized by acidic condition and lower nutrient contents of exchangeable bases, clay content, total carbon and available $P$. The soil properties presented in this study area might be result of nutrient loss from the soil due to prolonged of human activity, types of parent material and climatic condition.

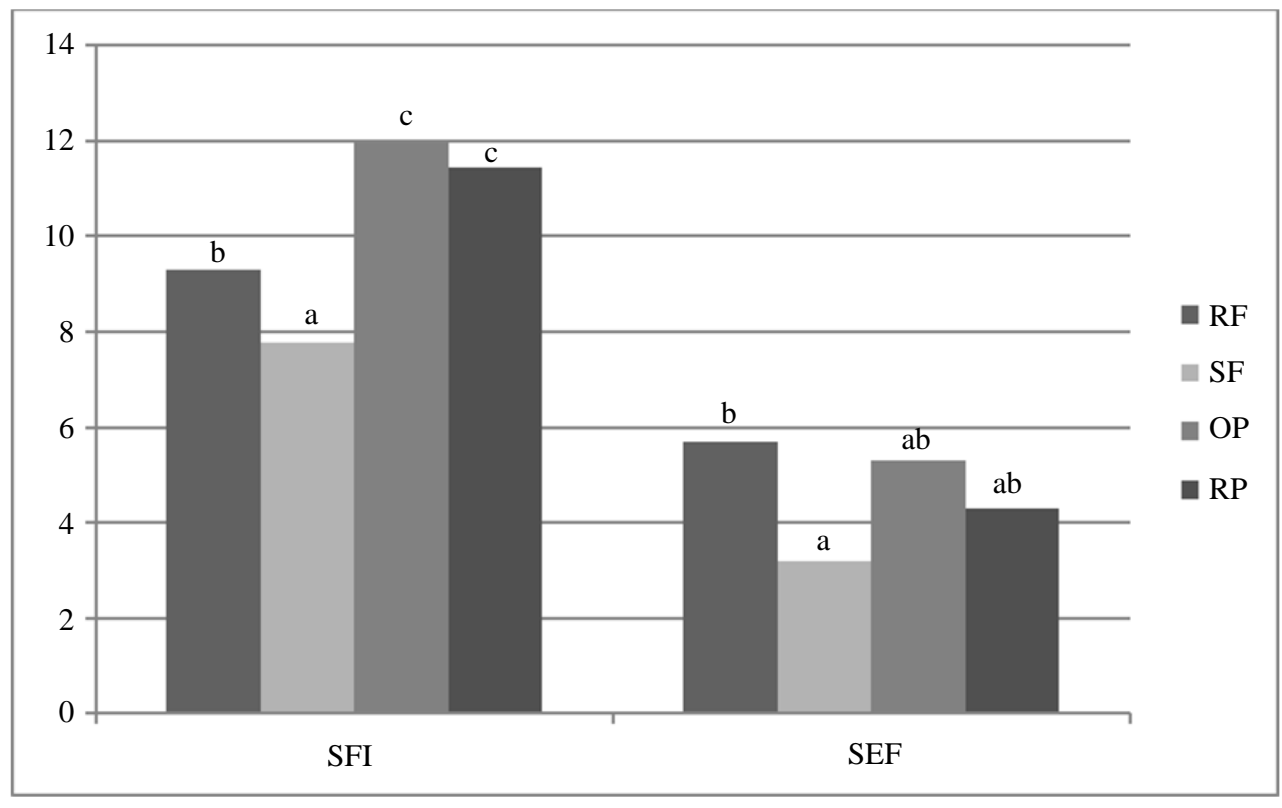

Fig. 3: The Soil Fertility Index (SFI) and Soil Evaluation Factor (SEF) comparison for Rehabilitated Forest (RF), Secondary Forest (SF), Oil Palm plantation (OP) and Rubber Plantations (RP) at surface soils $(0-15 \mathrm{~cm})$. Different letter(s) indicate significant differences among sites at $\mathrm{p} \leq 0.05$ using Tukey's HSD test 


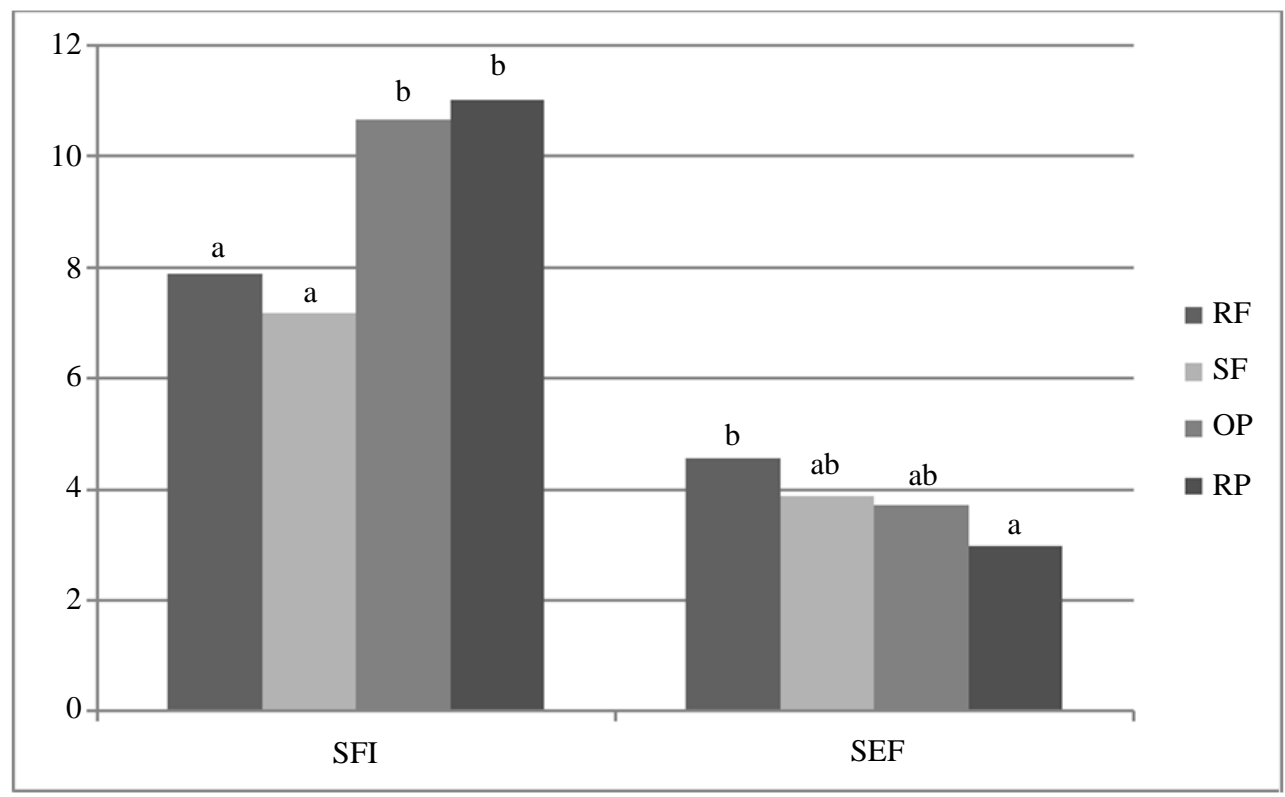

Fig. 4: The Soil Fertility Index (SFI) and Soil Evaluation Factor (SEF) comparison for Rehabilitated Forest (RF), Secondary Forest (SF), Oil Palm plantation (OP) and Rubber Plantations (RP) at subsurface soils $(15-30 \mathrm{~cm})$. Different letter(s) indicate significant differences among sites at $\mathrm{p} \leq 0.05$ using Tukey's HSD test

Akbar et al. (2010) and Lu et al. (2002) stated that if the SEF value was less than 5 , the soil did not reach the fertility status or extremely poor in nutrients content. However, factors such as climate, soil parent material and time could be causes of soil fertility status and therefore, it is need to be studied in greater aspect. The contribution of exchangeable $\mathrm{Al}$ in SEF probably affects to its value. If high amount of exchangeable $\mathrm{Al}$ is expressed, low SEF results could occur. If the soil is mature or highly weathered, the release of organic acids, mostly fulvic and humic acid are increased in the soil (Bautista-Cruz and del Castillo-Sànchez, 2005). The negative charge of these acids bond with $\mathrm{Al}^{3+}$ cations to form organometallic complexes, help to reduce exchangeable $\mathrm{Al}$ in the soil (Bautista-Cruz et al., 2012).

After the Soil quality Indices (SFI and SEF) were applied, the soil under oil palm and rubber plantations had a higher value compared to rehabilitation and secondary forests. It is likely that, the values were different because of the farm management practices, soil compaction/hardness and application of fertilizer. As we know, oil palm and rubber were fertilized for their products (fruits and rubber latex), but it is noted that no fertilizer application occurred at rehabilitated and secondary forests after planting. Therefore, comparisons between sites management and cost input were difficult to measure.

\section{The Relationships Among of the Selected Soil Chemical Properties and Soil Indices}

The correlation analyses were carried out to examine the roles of selected soil properties, SFI and SEF. Table 2 shows the results of Pearson correlation for selected soil chemical properties, SFI and SEF for all sites at $0-15 \mathrm{~cm}$ depth. There were significant positive correlation were found $\mathrm{pH}-\mathrm{KCl}$ with $\mathrm{pH}-\mathrm{H}_{2} \mathrm{O}$; $\mathrm{CEC}$ with $\mathrm{pH}-\mathrm{KCl}$ and $\mathrm{OM}$; $\mathrm{Mg}$ with CEC; $\mathrm{P}$ with CEC; silt fraction with exchangeable $\mathrm{Ca}, \mathrm{Mg}$ and available $\mathrm{P}$; SFI with $\mathrm{pH}-\mathrm{KCl}, \mathrm{OM}, \mathrm{CEC}, \mathrm{Mg}$ and clay fraction; and SEF with exchangeable $\mathrm{Ca}, \mathrm{Mg}$ and sand fraction. However, negative correlation were found $\mathrm{TC}$ with $\mathrm{pH}-\mathrm{H}_{2} \mathrm{O} ; \mathrm{CN}$ ratio with $\mathrm{pH}-\mathrm{KCl}$ and $\mathrm{TN} ; \mathrm{Al}$ with $\mathrm{pH}-\mathrm{KCl}, \mathrm{OM}$ and $\mathrm{CEC}$; sand fraction with exchangeable $\mathrm{Ca}$, available $\mathrm{P}$, Clay and silt fraction; SFI with exchangeable $\mathrm{Al}$; and $\mathrm{SEF}$ with sand fraction.

Table 3 shows the results of Pearson correlation for selected soil chemical properties, SFI and SEF for $15-30 \mathrm{~cm}$ depth for all sites. The positive relationships were found pH-KCl with $\mathrm{pH}-\mathrm{H}_{2} \mathrm{O}$; $\mathrm{CN}$ ratio with TC; $\mathrm{CEC}$ with $\mathrm{OM}$; exchangeable $\mathrm{Ca}$ with $\mathrm{pH}-\mathrm{H}_{2} \mathrm{O}$, TC and exchangeable $\mathrm{K}$; exchangeable $\mathrm{Al}$ with exchangeable $\mathrm{K}$; silt fraction with $\mathrm{CN}$; SFI with OM, CEC and clay fraction; and SEF with exchangeable $\mathrm{K}, \mathrm{Ca}$ and $\mathrm{Mg}$. However, there were negative correlation found $\mathrm{OM}$ with $\mathrm{pH}-\mathrm{H}_{2} \mathrm{O} ; \mathrm{CN}$ ratio with $\mathrm{TN}$; CEC with $\mathrm{pH}-\mathrm{H}_{2} \mathrm{O}$; exchangeable $\mathrm{K}$ with $\mathrm{OM}, \mathrm{CEC}$; exchangeable $\mathrm{Ca}$, OM and $\mathrm{CEC}$; clay fraction with exchangeable K; silt fraction with TN, sand fraction with clay and silt fraction; SFI with $\mathrm{pH}-\mathrm{H}_{2} \mathrm{O}$, exchangeable $\mathrm{K}$, $\mathrm{Ca}$ and $\mathrm{Al}$; and SEF with OM, CEC and SFI.

Similar with our findings Tilahun (2007) and Getahun et al. (2014) also found that OM significantly and positively correlated with cation exchange capacity. Tilahun (2007) also found a positive correlation between exchangeable $\mathrm{Ca}$ and $\mathrm{K}$. However, Ali et al. (2010) found $\mathrm{pH}-\mathrm{H}_{2} \mathrm{O}$ was positively correlated with $\mathrm{pH}-\mathrm{KCl}$ while negatively correlated with OM. 
Table 2: Correlation between selected soil properties, SFI and SEF at 0-15 cm depth for rehabilitated forest, secondary forest, oil palm and rubber plantations Correlations D1 $\left(\mathrm{r}^{2}\right)$

\begin{tabular}{|c|c|c|c|c|c|c|c|c|c|c|c|c|c|c|c|c|}
\hline & $\mathrm{pH}_{\mathrm{w}}$ & $\mathrm{pH}_{\mathrm{k}}$ & $\mathrm{OM}$ & $\mathrm{TC}$ & $\mathrm{TN}$ & $\mathrm{CN}$ & CEC & $\mathrm{Ca}$ & $\mathrm{Mg}$ & $\mathrm{Al}$ & $\mathrm{P}$ & $\mathrm{xc}$ & $\mathrm{Xs}$ & xsa & SFI & SEF \\
\hline $\mathrm{pH}_{\mathrm{w}}$ & 1 & & & & & & & & & & & & & & & \\
\hline $\mathrm{pH}_{\mathrm{k}}$ & $0.607^{*}$ & 1 & & & & & & & & & & & & & & \\
\hline $\mathrm{OM}$ & ns & ns & 1 & & & & & & & & & & & & & \\
\hline TN & ns & ns & ns & ns & 1 & & & & & & & & & & & \\
\hline $\mathrm{CN}$ & ns & $-0.524^{*}$ & ns & ns & $-0.896^{* *}$ & 1 & & & & & & & & & & \\
\hline CEC & ns & $.658^{* *}$ & $0.716^{* *}$ & ns & ns & ns & 1 & & & & & & & & & \\
\hline $\mathrm{Ca}$ & ns & ns & ns & ns & ns & ns & ns & 1 & & & & & & & & \\
\hline $\mathrm{Mg}$ & ns & ns & ns & ns & ns & ns & $0.503^{*}$ & ns & 1 & & & & & & & \\
\hline $\mathrm{Al}$ & ns & $-0.611^{*}$ & $-0.566^{*}$ & ns & ns & ns & $-0.632^{* * *}$ & ns & ns & 1 & & & & & & \\
\hline $\mathrm{P}$ & ns & ns & ns & ns & ns & ns & $0.540^{*}$ & ns & ns & ns & 1 & & & & & \\
\hline $\mathrm{xc}$ & ns & ns & ns & ns & ns & ns & ns & ns & ns & ns & ns & 1 & & & & \\
\hline Xs & ns & ns & ns & ns & ns & ns & ns & $0.711^{* *}$ & $0.509^{*}$ & ns & $0.566^{*}$ & ns & 1 & & & \\
\hline xsa & ns & ns & ns & ns & ns & ns & ns & $-0.740^{* *}$ & ns & ns & $-0.520^{*}$ & $-0.577^{*}$ & $-0.970^{* *}$ & 1 & & \\
\hline SFI & ns & $0.569^{*}$ & $0.899^{* *}$ & ns & ns & ns & $0.798^{* *}$ & ns & $0.540^{*}$ & $-0.712^{* *}$ & $0.701^{* *}$ & $\mathrm{~ns}$ & $\mathrm{~ns}$ & ns & 1 & \\
\hline SEF & ns & ns & ns & ns & ns & ns & ns & $0.828^{* *}$ & $0.811^{* *}$ & $\mathrm{~ns}$ & $\mathrm{~ns}$ & ns & $0.734^{* *}$ & $-0.704^{* *}$ & ns & 1 \\
\hline
\end{tabular}

Table 3: Correlation between selected soil properties, SFI and SEF at $0-15 \mathrm{~cm}$ depth for rehabilitated forest, secondary forest, oil palm and rubber plantations

\begin{tabular}{|c|c|c|c|c|c|c|c|c|c|c|c|c|c|c|c|c|}
\hline & $\mathrm{pH}_{\mathrm{w}}$ & $\mathrm{pH}_{\mathrm{k}}$ & $\mathrm{OM}$ & TC & $\mathrm{TN}$ & $\mathrm{CN}$ & CEC & $\mathrm{K}$ & $\mathrm{Ca}$ & $\mathrm{Mg}$ & $\mathrm{Al}$ & $\mathrm{xc}$ & Xs & xsa & SFI & SEF \\
\hline$\overline{\mathrm{pH}_{\mathrm{w}}}$ & 1 & & & & & & & & & & & & & & & \\
\hline $\mathrm{pH}_{\mathrm{k}}$ & $0.744^{* *}$ & 1 & & & & & & & & & & & & & & \\
\hline $\mathrm{OM}$ & $-0.762^{* *}$ & ns & 1 & & & & & & & & & & & & & \\
\hline $\mathrm{TC}$ & ns & ns & ns & 1 & & & & & & & & & & & & \\
\hline $\mathrm{TN}$ & ns & ns & ns & ns & 1 & & & & & & & & & & & \\
\hline $\mathrm{CN}$ & ns & ns & ns & $0.539^{*}$ & $-0.689^{* *}$ & 1 & & & & & & & & & & \\
\hline CEC & $-0.703^{* *}$ & ns & $0.919^{* *}$ & ns & ns & ns & 1 & & & & & & & & & \\
\hline $\mathrm{Ca}$ & $0.685^{* *}$ & ns & $-0.962^{* *}$ & $0.590^{*}$ & ns & ns & $-0.892^{* *}$ & $0.736^{* *}$ & 1 & & & & & & & \\
\hline $\mathrm{Mg}$ & ns & ns & $\mathrm{ns}$ & ns & ns & ns & ns & $\mathrm{ns}$ & ns & 1 & & & & & & \\
\hline $\mathrm{Al}$ & ns & ns & $\mathrm{ns}$ & ns & ns & ns & ns & $0.689^{* *}$ & ns & ns & 1 & & & & & \\
\hline $\mathrm{xc}$ & ns & ns & ns & ns & ns & ns & ns & $-0.669^{* *}$ & ns & ns & ns & 1 & & & & \\
\hline Xs & ns & ns & $\mathrm{ns}$ & ns & $-0.593^{*}$ & $0.535^{*}$ & ns & ns & ns & ns & ns & ns & 1 & & & \\
\hline xsa & ns & ns & $\mathrm{ns}$ & ns & ns & ns & ns & ns & ns & ns & ns & $-0.572^{*}$ & $-0.511^{*}$ & 1 & & \\
\hline SFI & $-0.671^{* *}$ & ns & $0.943^{* *}$ & ns & ns & ns & $0.925^{* *}$ & $-0.900^{* *}$ & $-0.904^{* *}$ & ns & $-0.583^{*}$ & $.578^{*}$ & ns & ns & 1 & \\
\hline SEF & ns & ns & $-0.837^{* *}$ & ns & ns & ns & $-0.682^{* *}$ & $0.600^{*}$ & $0.844^{* *}$ & $0.646^{* *}$ & ns & ns & ns & ns & $-0.728^{* * *}$ & 1 \\
\hline
\end{tabular}

Note: * and **: significant at $\mathrm{p} \leq 0.05$ and $\mathrm{p} \leq 0.01$, respectively and ns means non-significant

Tilahun (2007) also found a positive correlation $\mathrm{pH}-\mathrm{H}_{2} \mathrm{O}$ with exchangeable $\mathrm{Ca}$ and $\mathrm{CEC}$ with $\mathrm{Mg}$ while sand fraction was negatively correlated with exchangeable $\mathrm{Ca}$.

Positive correlation SFI with $\mathrm{pH}-\mathrm{KCl}, \mathrm{OM}, \mathrm{CEC}, \mathrm{Mg}$ and clay fraction while negative correlation SFI with exchangeable $\mathrm{Al}$ indicates that the high level of exchangeable $\mathrm{Al}$ could be the reason of low availability of other nutrients particularly phosphorus because nutrients fix by Al. This result also indicates that SFI can be used to estimate soil fertility status of studied areas. Arifin et al. (2008) and Zaidey et al. (2010) applied SFI and SEF for estimating soil fertility and site quality under dipterocarp plantation in rehabilitated degraded forestland in Perak, Malaysia.

\section{Conclusion}

This study showed that the soil fertility status of the soils in study areas was affected by soil compaction. The availability of nutrients reduced when its goes down to the deeper layer of soil (more than $15 \mathrm{~cm}$ depth). The compaction of soil also affected the distribution of active roots and the capability of roots to take the nutrients. Other than that, soil management, types of parent materials and climatic conditions, also affected nutrients availability. The application of soil indices in this study helps in finding a suitable method to assess the soil conditions in tropical forests. The soil under rehabilitated forest could be regarded as identical to those under secondary forest. This is proved that the rehabilitation programs could enhance the soil fertility status of degraded land due to logging activity and farming. However, the loss of nutrients from the fields with steep probably unavoidable under the tropical climate conditions in Sarawak. The availability of several nutrients such as organic matter and bases $(\mathrm{K}, \mathrm{Ca}$ and $\mathrm{Mg}$ ) were the crucial nutrient that needed by the plants for growth. The condition of $\mathrm{pH}$ of the soil plays the important role because it's affected the availability of organic matter decomposition, exchangeable bases and cation exchange capacity in the soil. From the viewpoint of soil fertility management, the appropriate managements and assessment of different kinds of land use (farming or rehabilitation), site history and soil characteristics will contributes to the sustainability of a farming or rehabilitation system with less impact on the surrounding environment. Therefore, examining the ecological significance of stand age and 
stress (disturbance) for function-based interpretations of soil quality indicators should be taken into consideration.

\section{Acknowledgment}

The researchers are grateful to the staffs of the Department of Crop Production, Universiti Putra Malaysia, Bintulu Sarawak Campus, Department of Land Management, Faculty of Agriculture and Department of Forest Production, Faculty of Forestry, Universiti Putra Malaysia during field sampling and laboratory analysis.

\section{Funding Information}

This study was financially supported by the Ministry of Higher Education of Malaysia (MOHE) under Fundamental Research Grant Scheme (FRGS) through Universiti Putra Malaysia, Malaysia (UPM).

\section{Author's Contributions}

Aiza Shaliha Jamaluddin: Organized the study, data collection of the study sample, analysis and writing of the manuscript.

Arifin Abdu: Designed the research plan, participated in the results analysis, contributed to the reviewing of the article critically.

Hazandy Abdul Hamid and Shamshuddin Jusop: Contributed in development of the conceptual framework, results analysis, drafting of the article.

Daljit Singh Karam Singh: Collect and process secondary data.

Md. Rezaul Karim: Contributed to the writing of the article, create discussion and correcting references and article review.

Md. Suzauddula: Ads Plagiarism check and review

Aizul Azfar Zulkeefli: Process the table data and review the article.

\section{Ethics}

The authors have no conflicts of interest in the development and publication of current research.

\section{References}

Aiza, S.J., A. Arifin, A.H. Hazandy, L.S. Abdul and N.M. Majid et al., 2012. Emphasizing the properties of soils occurring in different land use types of tropical rainforest in Sarawak, Malaysia. African J. Agric. Res., 7: 6479-6487.

Akbar, M.H., O.H. Ahmed, A.S. Jamaluddin, N.M. Majid and H.H. Abdul et al., 2010. Differences in Soil Physical and chemical properties of rehabilitated and secondary forests. Am. J. Applied Sci., 7: 1200-1209.
Ali, A., A. Esayas and S. Beyene, 2010. Characterizing soils of delbo we gene watershed, wolaita zone, Southern Ethiopia for planning appropriate land management. J. Soil Sci. Environ. Manage., 1: 184-199.

Arifin, A., S. Tanaka, S. Jusop, N.M. Majid and Z. Ibrahim et al., 2008. Assessment on soil fertility status and growth performance of planted dipterocarp species in Perak, Peninsular Malaysia. J. Applied Sci., 8: 3795-3805.

Aweto, A.O., 1987. Physical and nutrient status of soils under rubber (Heveabrasiliensis) of different ages in South-Western Nigeria. Agric. Syst., 23: 63-72.

Bautista-Cruz, A. and R.F. del Castillo-Sànchez, 2005. Soil changes during secondary succession in atropicalmonte cloud forest area. Soil Sci. Soc. Am. J., 69: 906-914.

Bautista-Cruz, A., R.F. del Castillo-Sànchez, J.D. Etchevers-Barra, M.C. Gutiérrez-Castorena and A. Baez, 2012. Selection and interpretation of soil quality indicators for forest recovery after clearing of a tropical montane cloud forest in Mexico. Forest Econ. Manage., 277: 74-80.

Beheshti, A., F. Raiesi and A. Golchin, 2012. Soil properties, $\mathrm{C}$ fractions and their dynamics in land use conversion from native forests to croplands in northern Iran. Agric. Ecosysts. Environ., 148: 121-133.

Ben-Dor, E. and A. Banin, 1989. Determination of organic matter content in arid-zone soils using a simple "loss-on-ignition" method. Soil Sci. Plant Anal., 20: 1675-1695.

Bray, R.H. and L.T. Kurtz, 1945. Determination of total organic and available forms of phosphorus in soils. Soil Sci., 59: 39-45.

Bremner, J.M. and C.S. Mulvaney, 1982. NitrogenTotal. In: Page: Methods of Soil Analyses, Part 2. Chemical and Mineralogical properties, Miller, A.L. and R.H. Keeney (Eds.), Monograph American Society Agron and Soil, Science Society American, Madison, WI, USA, pp: 595-624.

Celik, I., 2005. Land-use effects on organic matter and physical properties of soil in a southern Mediterranean highland of Turkey. Soil Till. Res., 83: 270-277.

Chinea, J.D., 2002. Tropical forest succession on abandoned farms in the Humacao Municipaly of eastern Puerto Rico. For. Ecol. Manage., 167: 195-207.

Doran, J.W. and T.B. Parkin, 1994. Defining and Assessing Soil Quality. In: Defining Soil Quality for a Sustainable Environment, Doran, J.W., D.C. Coleman, D.F. Bezdicekans and B.A. Stewart (Eds.), SSSA Special Publication, pp: 3-21.

Elliott, E.T., 1997. Rational for Developing Bioindicators of Soil Health. In: Biological Indicator of Soil Health, Pankhurst, C.E., B.M. Double and V.V.S.R. Gupta (Eds.), CAB International, Wellington, pp: 49-78. 
Gee, G.W. and J.W., Bauder, 1986. Particle-Size Analysis. In: Biological Indicator of Soil Health, Klute, A. (Ed.), Methods of Soil Analysis, Part 1. Physical and Mineralogical Methods, Agronomy Monograph, pp: 383-411.

Getahun, H., L. Mulugeta, I. Fisseha and S. Feyera, 2014. Impacts of land uses changes on soil fertility, carbon and nitrogen stock under smallholder farmers in central highlands of Ethiopia: Implication for sustainable agricultural landscape management around Butajiraarea. New York Sci. J., 7: 27-44.

Hardjowigeno, S., 2007. IlmuTanah. 1st Edn., MSP, Jakarta, ISBN-10: 9794550183.

Heryati, Y., A. Abdu, M.N. Mahat, H.H. Abdul and N.M. Majid et al., 2011. Comparing the fertility of soils under Khaya ivorensis plantation and regenerated degraded secondary forests. Am. J. Agric. Biol. Sci., 8: 472-480.

Huang, B., W. Sun, Y. Zhao, J. Zhu and R. Yang et al., 2007. Temporal and spatial variability of soil organic matter and total nitrogen in an agricultural ecosystem as effect by farming practices. Geoderma, 139: 336-345.

Ishizuka, S., S. Tanaka, K. Sakurai, H. Hirai and H. Hirotani et al., 1998. Characterization and distribution of soils at Lambir hills national park in Sarawak, with special reference to soil hardness and soil texture. Tropics, 8: 31-44.

Johnson, C.M., D.J. Zarin and A.H. Johnson, 2000. Postdisturbance aboveground biomass accumulation in global secondary forests. Ecology, 81: 1395-1401.

Jones, J.B.J., 2001. Laboratory Guide for Conducting Soil Test and Plant Analysis. 1st Edn., CRC-Press LLC, Florida, ISBN-10: 1420025295, pp: 384.

Lal, R., 1997. Residue management, conservation tillage and soil restoration for mitigating greenhouse effect by $\mathrm{CO}_{2}$-enrichment. Soil Tillage Res., 43: 81-107. DOI: 10.1016/S0167-1987(97)00036-6

Li, X.G., Y.K. Li, F.M. Ma, M. Zhang and P.L. Yin, 2009. Changes in soil organic carbon, nutrient and aggregation after conversion of native desert soil into irrigated arable land. Soil Till. Res., 104: 263-269.

Lu, D., E. Moran and P. Mausel, 2002. Linking Amazonian secondary succession forest growth to soil properties. Land Deg. Dev., 13: 331-343.

Mattsson, B., C. Cederberg and L. Blix, 2000. Agricultural land use in Life Cycle Assessments (LCA): Case studies of three vegetable oil crops. J. Clean. Prod., 8: 283-292.

Moran, E.F., E.S. Brondizio, J.M. Tucker, M.C. Da and Silva-Forsberg et al., 2000. Effects of soil fertility and land use on forest succession in Amazonia. For. Ecol. Manage., 139: 93-108.
Moscatelli, M.C., A. Di Tizio, S. Marinariand and S. Grego, 2007. Microbial indicators related to soil carbon in Mediterranean land use systems. Soil Till. Res., 97: 51-59.

Nye, P.H. and P.J. Greenland, 1964. Changes in the soil after clearing tropical forest. Plant Soil, 21: 101-112.

Ouyang, W., Y.M. Xu, F.H. Hao, X.L. Wangand and C.Y. Lin, 2013a. Effect of long-term agricultural cultivation and land use conservation on soil nutrient contents in the Sanjiang Plain. CATENA, 1: 243-250.

Ouyang, W., Y. Shan, F. Hao, S. Chen and X. Pu et al., 2013b. The effect on soil nutrients resulting from land use transformation in a freeze-thaw agriculture ecosystem. Soil Till. Res., 132: 30-38.

Pagliai, M., S. Pellegrini, N. Vignozzi, S. Rousseva and O. Grasselli, 2000. The quantification of the effect of subsoil compaction on soil porosity and related physical properties under conventional to reduced management practices. Adv. Geo. Ecol., 32: 305-313.

Pascarella, J.B., T.M. Aide, M.I. Serrano and J.K. Zimmerman, 2000. Land-use history and forest regeneration in the Cayey Mountains, Puerto Rico. Ecosystem, 3: 217-228.

Peli, M., A. Husni and M.Y. Ibrahim, 1984. Report and map of detailed soil survey of UPM Farm, Bintulu Campus, Sarawak. UPM Sarawak Campus Tech., 1: 73-73.

Raise, F., 2007. The conversion of overgrazed pastures to almond orchards and alfalfa cropping systems may favor microbial indicator of soil quality in Central Iran. Agric. Ecosyst. Environ., 112: 13-20.

Reijneveld, A., J. van Wensemand and O. Oenema, 2009. Soil organic carbon contents of agricultural land in the Netherlands between 1984 and 2004. Geoderma, 252: 231-238.

Sakurai, K.S., I.S. Tanaka and M. Kanzaki, 1998. Differences in soil properties of dry evergreen and dry deciduous forests in the Sakaerat Environment Research Station. Tropics, 8: 61-80.

Schumacher, B.A., 2002. Method for the determination of Total Organic Carbon (TOC) in Soils and sediments. U.S. Environ. Prot. Agency, Las Vegas.

Soane, B.D. and C. Ouwerkerk, 1995. Implications of soil compaction in crop production for the quality of the environment. Soil. Till. Res., 35: 5-22.

Solomon, D., J. Lehmann and W. Zech, 2000. Land use effects on soil organic matter properties of Chromic Luvisols in semi-arid northern Tanzania: Carbon, nitrogen, lignin and carbohydrates. Agric. Ecosyst. Environ., 78: 203-213.

Sumner, M.E. and B.A. Stewart, 1992. Soil Crusting: Chemical and Physical Processes. 1st Edn., Lewis Publishers, Boca Raton, Fla, ISBN-10: 0873718690, pp: 623. 
Tanaka, S., S. Tachibe, E.W. Mohd, L. Jonathan and S. Logie et al., 2009. Soil characteristics under cash crop farming in upland areas of Sarawak, Malaysia. J. Agric. Ecosyst. Environ., 129: 293-301.

Tilahun, G., 2007. Soil fertility status as influenced by different land uses in Maybar areas of South Wello zone, North Ethopia. MSc Thesis, Haramaya University.

Wicke, B., R. Sikkema, V. Dornburg and A. Faaij, 2011. Exploring land use change and the role of oil palm production in Indonesia and Malaysia. Land Use Pol., 28: 193-206.
Zaidey, A.K., A. Arifin, I. Zahari, A.H. Hazandy and M.H. Zak et al., 2010. Characterizing soil properties of low land and hill forests at Peninsular Malaysia. Int. J. Soil. Sci., 5: 112-130.

Zornoza, R., J. Mataix-Solera, C. Guerrero, V. Arcenegui and J. Mataix-Beneyto et al., 2008. Validating the effectiveness and sensitivity of two soil quality indices bases on natural forest soils under Mediterranean conditions. Soil Biol. Biochem., 40: 2079-2087. 